\title{
DUBROWNICKI BENEDYKTYN LUDWIK TUBERON DE CRIEVA (CRIJEVIĆ) I JEGO ZARYS DZIEJÓW TURCJI W PAMIECTNIKU POLITYCZNYM COMMENTARII DE TEMPORIBUS SUIS ${ }^{1}$
}

\author{
PIOTR WRÓBEL
}

\begin{abstract}
Piotr Wróbel, Dubrownicki benedyktyn Ludwik Tuberon de Crieva (Crijević) i jego zarys dziejów Turcji w pamiętniku politycznym Commentarii de temporibus suis (Ludwik Tuberon de Crieva (Crijević) the benedictine from Dubrovnik and his outline of the history of Turkey in the political memoir Commentarii de temporibus suis).

One of the first writers from Dubrovnik who has attempted to write a comprehensive history of Turkey a Benedictine Louis de Crieva called Tubero (1458-1527). In the sixth book of his political memoir Commentarii de temporibus suis, he provided a description of the origin, customs and outline of the history of the Turks.
\end{abstract}

KEYwORDs: Ludwk Tuberon de Crieva; Dubrovnik; Turcja; Commentarii

Balcanica Posnaniensia. Acta et studia, XXI, Poznań 2014, Wydawnictwo Instytutu Historii UAM, pp. 51-62, ISBN 978-83-63047-59-7, ISSN 0239-4278. Polish text with a summary in English.

Piotr Wróbel, Uniwersytet Jagielloński, Instytut Historii, ul. Gołębia 13, 31-007 Kraków, Polska - Poland, piotr.wrobel@uj.edu.pl.

Z racji swych długotrwałych relacji z Turkami oraz szczególnego położenia politycznego wiedza na temat religii, zwyczajów i przeszłości Turków w późnośredniowiecznym Dubrowniku zapewne była szersza niż w innych krajach chrześcijańskich. Jednak do końca XV w. tematyka osmańska była raczej omijana w dziełach pisarzy dubrownickich, do czego prawdopodobnie przyczyniała się cenzura ze strony władz ${ }^{2}$. Sytuacja polityczna w jakiej znajdowała się Republika Dubrownicka była jeszcze zbyt niepewna, aby można było pozwolić obywatelom na swobodne wypowiadanie się na temat Turcji i Turków. Z początkiem XVI wasalny status Dubrownika, otoczo-

\footnotetext{
${ }^{1}$ Autor przygotowuje do druku polski przekład dzieła Ludwika Tuberona de Crieva na podstawie wydania dubrownickiego z $1784 \mathrm{r}$. Wszystkie cytaty pochodzą z tego tłumaczenia a podane w tekście strony odwołują się do wspomnianego wydania. Pomocą przy tłumaczeniu służyło krytyczne chorwackie wydanie dzieła Tuberona znakomitego latynisty Vlado Rezara opatrzone licznymi przypisami oraz obszernym wstępem. Por:: Ludovici Cervarii Tuberonis patritii Rhacusini ac abbatis congregationis melitensis Commentaria suorum temporum, Rhacusii 1784. (dalej cyt. Commentaria...); Ludovik Crijević Tuberon, Komentari o mojem vremenu, Zagreb 2001.

${ }^{2}$ Doskonale ilustruje to np. dzieło Filipa de Diversisa, który w poł. XV wieku opisał szczegółowo Raguzę, nie wspominając ani słowa o Turkach. Patrz: Filip de Diversis, Opis Dubrownika, Kraków 2004, s. 20-21.
} 
nego przez posiadłości sułtańskie, zdawał się już utrwalony. Miasto stało się ważnym pośrednikiem w handlu z Imperium Osmańskim oraz cennym źródłem informacji dyplomatycznych o wydarzeniach w Porcie ${ }^{3}$.

Jednym z pierwszych pisarzy dubrownickich, który podjął próbę całościowego (choć skrótowego) ujęcia dziejów Turcji był benedyktyn Ludwik de Crieva zwany Tuberonem (1458-1527) ${ }^{4}$. Członek znanego szlacheckiego rodu, po powrocie ze studiów w Paryżu w 1484 r. wstąpił do zakonu benedyktynów i osiadł w klasztorze na Wyspie św. Andrzeja, gdzie spędził 18 lat $^{5}$. Bardzo dobra orientacja w sprawach węgierskich jaką wykazywał potem w swej pracy sugeruje, że mógł w tym czasie podróżować do tego kraju, choć nie ma na to pewnych dowodów. W 1502 r. Tuberon objął funkcję opata w klasztorze św. Jakuba w Višnjicy w bezpośrednim sąsiedztwie Dubrownika $^{6}$. W 1508 r. za zgodą władz Republiki udał się w odwiedziny do arcybiskupa Kalocs Grzegorza Frankapana, z którym łączyła go przyjaźń ${ }^{7}$. Ludwik Crieva był też aktywny w samym Dubrowniku. W 1515 r. i (po rezygnacji w 1517 r.) ponownie w 1522 r. został wybrany, wbrew prawu Republiki, na urząd wikariusza tamtejszego arcybiskupa ${ }^{8}$. Przeciwny planom władz Dubrownika dotyczącym wcielenia klasztoru w Višnjicy do tworzonej kongregacji benedyktyńskiej Ludwik podjął w 1525 r. zabiegi o uzyskanie dla siebie biskupstwa Stonu, które chciał wydzielić z biskupstwa Korčuli ${ }^{9}$. Nie zdążył jednak przed swą śmiercią w 1527 r. zrealizować tego ambitnego planu, który urzeczywistnił się nieco później ${ }^{10}$.

Choć Tuberon, jako prawdziwy humanista, zajmował się różnymi formami działalności literackiej, w tym także poezja, dziełem jego życia były Commentarii de

${ }^{3} \mathrm{O}$ roli Dubrownika jako centrum wymiany informacji ostatnio obszernie w zbiorze artykułów: Tajna diplomacija u Dubrovniku u XVI. stoljeću, ured. M. Polić-Babić, B. Baletić, L. Čoralić, Zagreb 2011, passim.

${ }^{4}$ Poza materiałami znajdującymi się w Archiwum Państwowym w Dubrowniku duże znaczenie dla odtworzenia życia oraz twórczości Tuberona ma jego szczegółowa biografia w pochodzącym z XVIII w. w dziele jego dalekiego krewnego Serafina Marii de Crieva Bibliotheca Ragusina. Patrz: S. M. Cerva, Bibliotheca Ragusina, t. I, Zagrabiae 1975, s. 40-58; S. Antoljak, Crijević Ludovik Tuberon [w:] Hrvatski biografski leksikon, Zagreb 1989, vol. 2, s. 719-720.

${ }^{5}$ Državni Arhiv u Dubrovniku [DAD] Testamenta Notariae vol. 25, f. 105-105'; K. Jireček, Beiträge zur ragusanischen Literaturgeschichte, „Archiv für Slavische Philologie”, Bd. XXI, Berlin 1899, s. 448$-451$.

${ }^{6}$ DAD Acta Consilii Rogatorum, vol. 29, f. 76; V. Rezar, Dubrovački humanistički historiograf Ludovik Crijević Tuberon, „Anali”, vol. 37, Dubrovnik 1999, s. 55; S. M. Cerva, op. cit., s. 42.

${ }^{7}$ Relacje jakie łączyły Grzegorza Frankapana z Tuberonem podobnie jak jego inne kontakty z Węgrami, mimo postulatu jaki przed stuleciem wysunął jeszcze Konstantin Jireček, nie zostały wciąż dostatecznie zbadane. Wiadomo jednak, że właśnie arcybiskupowi Kalocs Grzegorzowi Frankapanowi dubrownicki pisarz poświęcił swe dzieło. Patrz: K. Jireček, Der ragusanischer Dichter Šiško Menčetić, „Archiv für Slavische Philologie”, B. XIX, Berlin 1897, s. 51; DAD Acta Consilii Rogatorum, vol. 31, f. $55^{\prime}$.

${ }^{8}$ DAD Acta Consilii Rogatorum, vol. 34, f. 33, 108', 145, 145', 146, vol. 36, f. 216.

9 DAD Acta Consilii Rogatorum, vol. 38, f. 29'.

10 DAD Testamenta Notariae, vol. 34, f. 89-90'; V. Lupis, Pregled povijesti stonske biskupije od osnutka do 1541. godine [w:] Tisuću godina upostave Dubrovačke nadbiskupije, Dubrovnik 2001, s. 211-212 . 
temporibus suis, rodzaj pamiętnika politycznego, wzorowanego przypuszczalnie na dziele papieża Piusa II pod podobnym tytułem ${ }^{11}$. Podzielone na jedenaście ksiag Commentarii obejmują wydarzenia z lat 1490-1522 czyli współczesne autorowi. Co ciekawe, wyizolowany i osamotniony w klasztorze w Višnjicy zakonnik nie opisywał w swym dziele lokalnych wydarzeń z rodzinnego Dubrownika (co mogło być niemożliwe z racji tajemnicy i cenzury jaką w Republice rozciągano nad działalnością polityczną i dyplomatyczną) ale poświęcił swe dzieło szerszej scenie politycznej, zwłaszcza sprawom węgierskim. Narrację rozpoczął od zaburzeń, jakie nastąpiły w tym kraju po śmierci Macieja Korwina a skończył na konsekwencjach zdobycia Belgradu przez Turków. Tuberon nie stronił przy tym w swym obszernym dziele od wątków pobocznych. Poza kwestiami węgierskimi znajdujemy tam ciekawe informacje dotyczące spraw polskich, ruskich, mołdawskich, austriackich a nawet włoskich czy hiszpańskich. W ostatniej księdze znalazł się np. dość obszerny opis wydarzeń związanych $\mathrm{z}$ aktywnością papieży i Ligą z Cambrais ${ }^{12}$. Tuberon nie unikał opisów geograficznych (np. opis Węgier, czy Dalmacji) a w dygresjach także retrospekcji sięgającej głęboko do genezy zdarzeń (np. ciekawy obraz powstania Węgier w księdze pierwszej czy opis przybycia Słowian na Bałkany i zarys dziejów Dubrownika w księdze piątej) ${ }^{13}$. Czytelnika nieco obeznanego z dziełami powstałymi w Dubrowniku, zastanawiają uwagi krytyczne jakie autor Commentarii kierował wobec swego rodzinnego miasta np. niezwykła w Dubrowniku krytyka handlu, który był przecież podstawą egzystencji raguzańskiej szlachty - a bardziej jeszcze - bardzo ostra krytyka obyczajów duchownych i sytuacji w Kościele ${ }^{14}$.

Naturalnie kluczową rolę w Commentarii odgrywają Turcy, którzy - jako główni adwersarze Węgrów - pojawiają się w różnych kontekstach na licznych kartach dzieła. Wiele wskazuje, iż właśnie informacje na temat Turkow uznawano w XVI w. za najbardziej interesujące w dziele Tuberona. Były one też pierwszymi fragmentami jego pracy, które doczekały się druku. Dzięki staraniom dubrownickiego szlachcica Mateo de Bona oraz rektora tamtejszej szkoły Francesca Serdonata w 1590 r. we Florencji zostały wydane przez Antonia Patavini jako odrębne dzieło pod tytułem: Ludovicii Cervarii Tuberonis, patricii Rhacusani, abbatis divi Jacobi De Turcarum origine moribus et rebus gestis commentarius. W pięciu księgach został tam z drobnymi tylko zmianami, służącymi połączeniu odległych tematycznie fragmentów, za-

11 Dzieło Piusa II wydał w 1984 r. Adrian van Heck, natomiast na język polski przełożył w 2005 r. ks. bp. Julian Wojtkowski, niestety bez przypisów i komentarza. Patrz: Pii II, Commentarii rerum memorabilium que temporibus suis contigerunt, ed. ab Adriano van Heck,, vol. I-II, Citta del Vaticano 1984; Pius II, Pamiętniki, przełożył bp Julian Wojtkowski, Michalineum 2005.

12 Commentaria..., t. II, s. 279-284.

13 Commentaria...,t. I, s. 18-22, 187-208.

14 Za ilustrację może tu służyć jedno krytyczne zdanie z księgi V: Mianowicie, po prostu żadne sława nie może się wiąać z miastem, które zajmuje się tylko handlem a unika wojny. Nie powinno zatem dziwić, iż dzieło Tuberona znajdowało się od 1734 r. na dubrownickim Indeksie ksiag zakazanych i nie mogło być wydane w mieście bez specjalnej zgody władz Dubrownika. Por.: V. Rezar, Dubrovački..., s. 79; Ž. Muljačić, O prvoj dubrovačkoj tiskari, ,Anali” vol. 4/5, Dubrovnik 1956, s. 583-612. 
warty cały materiał z Commentarii dotyczący Turków z ksiąg od szóstej do jedenastej ${ }^{15}$.

W niniejszym artykule analizie poddany zostanie jedynie niewielki, ale chyba najważniejszy, fragment dzieła Ludwika de Crieva dotyczący dziejów tureckich. Chodzi o opis pochodzenia, obyczajów i zarys dziejów Turków zamieszczony w szóstej księdze Commentarii i zajmujący ok. 1/3 jej objętości. Fragment ten ma formę zwartej dygresji i został wyraźnie wydzielony z toku narracji ${ }^{16}$. Jego analiza, dostarcza ciekawych informacji nie tyle na temat samych Turków, co zasobu wiedzy o nich oraz sposobu postrzegania ich historii przez ówczesnych Dubrowniczan.

Pisząc o pochodzeniu Turków Tuberon wyraźnie zaznacza, iż wiadomości zaczerpnął od „scytyjskich” autorów (...apud Scythas authores reperio), co zdaje się sugerować, iż może znane mu były jakieś tureckie kroniki ${ }^{17}$. Ludwik na tej bazie przychyla się do stanowiska, iż pierwotnie Turcy pochodzili przypuszczalnie z Chin (...quam nunc uulgo Cathaiam appellant). Uważa za pewne, iż wspólnie z Tatarami mieszkali później na Kaukazie, skąd w 755 r. przeszli do Albanii. Stamtąd przekroczywszy rzekę Cyre „wkrótce” (moxque) najechali Wielką Armenię (Armeniam Maiorem). Po długich walkach z Persami i Saracenami (...cum Persis et Sarracenis, gente Arabica) zdobyli znaczną część Azji Mniejszej ${ }^{18}$. Warunkiem pokoju, jaki z nimi ostatecznie zawarli, było przyjęcie islamu oraz walka z chrześcijanami a zwłaszcza zwalczanie braci Godfryda i Baldwina (Gothifredum (...) atque Balduinum fratres), co jest jednoznacznym nawiązaniem do postaci z okresu pierwszej wyprawy krzyżowej ${ }^{19}$. Turcy szybko wyparli jednak zarówno lokalnych władców chrześcijańskich, jak perskich, zagarniając całą Małą Azję dla siebie. Po wymarciu królewskiego rodu Hunkara tureccy namiestnicy: Othomanus, Hermenes, Scarchanus, Germenes, Andinus, Mentheses, Caramanus, podzielili między siebie kraj. Warto zauważyć, iż Tuberon imiona namiestników wywodzi od nazw bejlików tureckich z początku XIV w., zachowując przy tym zdumiewającą dokładność. Co ciekawe, trafnie zauważył, że potomkowie Hermenesa (Alaedini) oraz Karamanowie wciąż żyli w jego czasach ${ }^{20}$.

${ }^{15}$ Możliwe, że (jak twierdził w XVIII w. Serafin M. Crieva) sam Tubero uznał fragmenty dotyczące Turcji i Dubrownika za najważniejsze i tylko one miały zostać z jego spuścizny dla potomnych. Inne części, być może z uwagi na wspomniane uwagi krytyczne wobec elity Republiki oraz Kościoła, nie były przeznaczone dla powszechnej wiadomości. Por.: S. M. Cerva, Bibliotheca ..., s. 420-421.

${ }^{16}$ Fragment rozpoczyna się od zdania: De Turcarum antiqua patria duplicem famam apud Scythas auctores reperio. Kończy zaś: His de Othomanorum origine atque imperio, Turcarumque moribus dictis, ad ea quae intermiseram iam regrediar. Patrz: Commentaria, t. I, s. 253-275.

${ }^{17}$ Niestety trudno ustalić o jakich autorach może być tutaj mowa. Na temat wczesnej historiografii tureckiej patrz: F. Babinger, Die Geschichtschreiber der Osmanen und ihre Werke, Leipzig 1927, s. 7-71; H. Inalcik, The Rise of Ottoman Historiography [w:] Historians of the Middle East, by B. Lewis and R.M. Holt, London 1962, s. 152-167.

18 Oczywiście opisane początki dziejów Turków odnosza się jeszcze do Seldżuków. Por.: Commentaria..., t. I, s..254; C. Cahen, Pre-Ottoman Turkey, New York 1968, s. 1-66.

${ }^{19}$ Commentaria..., t. I, s. 254.

${ }^{20}$ Commentaria..., t. I, s. 255; E. Werner, Die Geburt einer Grossmacht-Die Osmanen, Weimar 1985, s. 91-95; P. Wittek, Fürstentum Mentesche. Studie zur Geschichte Westkleinenasiens im 13.-15. Jh., Istanbul 1934, s. 11-23; P. Wróbel, Geneza państwa Osmanów a migracje i przemiany etniczne w Azji 
Pisząc o początkach sułtańskiego rodu Tuberon nie wspomina imienia Ertogrula. Stwierdza jedynie słusznie, że Osman - przodek wielkich władców tureckich, władał pierwotnie obszarem wokół miasta Dorilia (tureckie Eskišehir) w Wielkiej Frygii. Wykorzystując ogólny nieporządek zagarnął później znaczny obszar, stając się równie bogaty jak azjatyccy władcy (...Asiae praefectorum uiribus par esset). $Z$ drugiej strony, wskazując na wciąż podrzędny status Osmana, autor dzieła zauważa, że kiedy nieco uporządkowano sprawy polityczne pozwolono zachować Osmanowi część Myzji i Wielką Frygię (partem Mysiae, addita Maiore Phrygia) ${ }^{21}$. Z naciskiem, choć bez uznania, Tuberon podkreśla waleczność Osmana, który ...wszystkich sasiadów, a najbardziej chrześcijan, którzy w owym czasie zasiedlali Azję, ogłosit swymi nieprzyjaciótmi ${ }^{22}$.

Dubrownicki dziejopisarz znaczenie więcej informacji podał na temat syna Osmana - Orchana. Poza zdobyciem Brusy, a później całej Bitynii, szczególnym sukcesem tego władcy miało być przeniesienie podbojów na kontynent europejski ${ }^{23}$. Tuberon przypisuje tu winę cesarzowi Janowi Paleologowi, który szukając sojuszników w wojnach przeciw Bułgarom, Macedończykom i Wołochom zawarł przymierze z Orchanem ${ }^{24}$. Jako warunek sojuszu Turek postawił przekazanie Gallipoli i Sestu ( ...nisi prius in potestetem Sestos cum Callipoli trederentur), bowiem bał się przejścia przez Hellespont ${ }^{25}$. Wkrótce zażądał też od cesarza Chersonezu z Lizymachią, rzekomo po to by zapewnić paszę dla licznych koni tureckich. Cesarz Jan - jak pisze Ludwik - zaślepiony nienawiściq do Bułgarów, nie bacząc na to, że ma do czynienia $\mathrm{z}$ innowierca, przekazał mu żądane ziemie ${ }^{26}$.

Zaskakująco mało wie natomiast Tuberon o czynach Murada I oraz jego bezpośredniego następcy. Wspomina wprawdzie jego wielką wyprawę na Europę, w trakcie której miał dojść aż do rzeki Maricy, nie podaje jednak żadnych informacji o zdobyciu Adrianopola, a tym bardziej o przeniesieniu tam stolicy. Zapewne aby wypełnić

Mniejszej w świetle badań [w:] Wędrówka i etnogeneza w starożytności i w średniowieczu, pod. red. M. Salamona i J. Strzelczyka, Kraków 2010, s. 473-491.

${ }^{21}$ Por.: Commentaria..., t. I, s. 255-256; H. Inalcik, An Overwiew of Ottoman History [w:] The Great Ottoman-Turkish Civilisation, vol. I, Ankara 2000, s. 7-13.

${ }^{22}$ Commentaria..., t. I, s. 256.

23 ...ad parentis Regnum totam fere Bythiniam adiecit, expugnata prius Prusa urbe in radicibus Olympi montis posita . Patrz: Commentaria..., t. I, s. 257.

${ }^{24}$ Wiadomo, że to nie Jan V Paleolog, ale walczący przeciw niemu Jan Kantakuzen sprowadził jako pierwszy posiłkowe oddziały tureckie do Europy między 1329 a 1344 r. Turcy ci pochodzili z Aydinu i podlegali Umur Beyowi. Prawdopodobnie dopiero w 1346 r. Kantakuzen zwrócił się o pomoc do Orchana, któremu oddał wówczas córkę Teodorę za żonę. Patrz: H. Inalcik, An Overview..., s. 30.

${ }^{25}$ Gallipoli zostało zajęte przez Sulejmana syna Orchana po uszkodzeniu murów twierdzy w wyniku trzessienia ziemi w marcu 1353 r. Patrz: M. Kiel, The incorporation of the Balkans into the Ottoman Empire 1353-1453 [w:] The Cambridge History of Turkey, vol. 1, Cambridge 2009, s. 145.

${ }^{26}$ Zagarnięcie przez Turków Półwyspu Galipoli można tylko pośrednio łączyć z walkami na Bałkanach. Wrogami Jana Kantakuzena (a nie Jana V) byli wówczas Serbowie a nie Bułgarzy. Por.: Commentaria..., t. I, s.258; H. Inalcik, An Overview..., s. 30. 
lukę w narracji podkreśla jedynie mało istotny fakt umocnienia przez Turków murów Gallipoli na Chersonezie ${ }^{27}$.

Jedynym wydarzeniem, które Ludwik uznał za warte zapisania z czasów Bajezyda I był konflikt tego sułtana $z$ mongolskim władcą Tamerlanem o panowanie nad Małą Azją. Charakterystyczne, iż Tuberon zdaje się przychylać do racji Tamerlana, gdy stwierdza: Skadinqd wydawało się, że Tamerlan, który byt $w$ dalekim pokrewieństwie z dawnymi władcami tureckimi, zdobywa dla siebie Mała Azje zgodnie z prawem dziedziczenia ${ }^{28}$. Nie bez mściwej satysfakcji informuje też kronikarz o nieszczęśliwym dla Bajezyda wyniku starcia. Po przegranej bitwie Tamerlan traktował ze wzgardą wziętego do niewoli sułtana. Jak pisze Ludwik: Oprócz innych poniżeń, które mu zadawat, zakut [go] w kajdany aby obok jego toża leżat $i$ kiedy sam ucztowat, jak pies gryzt kości, które rzucil mu ze stotu ${ }^{29}$.

Tuberon nic nie wie o zażartej rywalizacji synów Bajezyda I o schedę po oj$\mathrm{cu}^{30}$. W jego narracji po wycofaniu się Tamerlana w Brusie sułtanem wybrany został Musa, który zawarł pokój z sąsiadami w Azji a swą uwagę skierował znowu na podbój chrześcijańskiej Europy. Tutaj miał ze zmiennym powodzeniem walczyć w Tracji, gdzie ostatecznie pokonał króla Wukaszyna (Vucasino) wygrywając bitwę pod bramami Adrianopola. Następnie przeniósł turecką stolicę do tego miasta, ponieważ spodobało mu się jego położenie ${ }^{31}$. Jak widać Tuberon łączy prawdziwe wydarzenia z okresu panowania Murada I tj. bitwę nad Maricą z królem Wukaszynem (1371) oraz zdobycie Adrianopola (1364) w jedno i przesuwa na burzliwe dla Turcji czasy panowania Musy. Widać, iż w pamięci Dubrowniczan z jego epoki wszystkie te ważne wydarzenia pozostały, trudno je jednak było dokładnie lokować chronologicznie.

W dalszej części swej narracji Tuberon, pozbawiony widać wiarygodnych źródeł, coraz poważniej rozmija się z prawdą, tym razem myląc nawet tureckich władców. Według niego bowiem po Musie sułtanem miał zostać Bajezyd II (Bajazethes Secundus). ${ }^{32}$ Jemu Ludwik przypisuje wielką wyprawę za Strumę (Strymon) przeciw władcom Serbów i Macedończyków (Dardani ac Macedonum reguli) zakończoną bitwą z królem Serbów Lazarem (Lazarus, Dardanorum rex). Wprawdzie kronikarz nigdzie nie podaje ani daty ani nazwy miejsca bitwy jednak bazując zapewne na krążących opowieściach (a może wykorzystując także pisemne przekazy?) wyjątkowo

27 Por.: Commentaria..., t. I, s. 259; G. Agoston, Murad I (1362-1389) [w:] Encyclopedia of the Ottoman Empire, New York 2009, s. 396-399.

28 Por.: Commentaria..., t. I, s. 260; G. Agoston, Bayezid I Yildirim or Thunderbolt (1389-1402) [w:] Encyclopedia..., s. 80-82.

${ }^{29} \mathrm{O}$ zupełnie innym traktowaniu Bajezyda I w niewoli pisze Szaraf ad-Din. Por.: Commentaria..., t. I, s. 260; M. Małowist, Tamerlan i jego czasy, Warszawa 1985, s. 75-76.

30 Najszerzej o tym ostatnio: D.J. Kastritsis, The Sons of Bayezid. Empire Building and Representation in the Ottoman Civil War of 1402-1413, Leiden-Boston 2007, passim.

31 Commentaria..., t. I, s. 261.

32 Oczywiście, z burzliwego okresu walk wewnętrznych (1402-1413) w rzeczywistości zwycięsko wyszedł Mehmed I, którego Tuberon myli z Bajezydem II. W dodatku na czas panowania tego władcy lokuje wydarzenia związane z bitwą na Kosowym Polu z 1389 r. Patrz: G. Agoston, Mehmed I Celebi (1413-1421) [w:] Encyclopedia...., s. 362-364. 
obszernie opisał towarzyszące jej wydarzenia. W pierwszym rzędzie skoncentrował się na żywym w tradycji ludowej, wątku konfliktu księcia Lazara ze swym rycerzem Miloszem (Milon). Ten ostatni, oskarżony nieprawdziwie o zdradę aby dowieść swej niewinności, wkradł się w łaski sułtana i zamordował go podstępnie. W trakcie próby ucieczki został jednak zasieczony przez straże a jego posrebrzana ręka symbolicznie została uwieszona przy grobie Bajezyda II w Brusie ${ }^{33}$. Tuberon dał też krótki, ale dramatyczny opis bitwy, w której pierwszej fazie zwycięstwo chyliło się na stronę chrześcijan by ostatecznie przypaść muzułmanom. Mimo generalnej niechęci do Turków pisarz przy okazji podkreśla ich zalety: umiejętność zachowania tajemnic, zwłaszcza złych wieści, zapał bojowy i umiłowanie do wojennej sławy ${ }^{34}$. Przypieczętowaniem klęski wojsk serbskich była śmierć Lazara, który według Tuberona miał zginąć w czasie ucieczki, po daremnych wysiłkach aby skłonić wojska do walki ${ }^{35}$.

Tuberon, widać niezbyt pewny swych wiadomości co do dalszych dziejów Turcji, zdawkowo opisał panowanie następcy zabitego sułtana Bajezyda II, którym miał być rzekomo jego syn Mehmed I: Cesarz ten w starciu z chrześcijanami nie uczynit nic wartego wzmianki oprócz zniszczenia i jednej iliryjskiej bitwy z iliryjskimi ksiażętami nad rzeka Drina, znanej z klęski Turków ${ }^{36}$. Równie krótko wspomina następnie o rządach Isy (?) (Hyladinius), który poza częstym pustoszeniem krajów chrześcijańskich na Bałkanach miał stoczyć nierozstrzygniętą (!) (aequo marte semel pugnauit) bitwę $\mathrm{z}$ cesarzem Zygmuntem pod Nikopolis ${ }^{37}$.

Znacznie dokładniej znane były Tuberonowi rządy kolejnego władcy na tronie sułtańskim - Murada II, którego tytułuje Homurathes cognomento Magnanimus, uważając iż był to: ...najstawniejszy cesarz $i$ wojnie $i$ w pokoju. W zasadzie trafnie przypisał mu też podboje: Pod swa władzę zagarnąt on cała Trację oprócz Konstantynopola,

\footnotetext{
${ }^{33} \mathrm{Na}$ temat tradycji bitwy na Kosowym Polu obszernie J. Ređep, Por.: J. Ređep, The Legend of Kosovo, „Oral Tradition”, vol. 6 (2-3), 1991, s. 253-265. Commentaria..., t. I, s. 261-263.

34 Zalety Turków podkreśla opis ich postawy po podstępnym zamordowaniu sułtana: Choć mocno wzburzeni śmiercia cesarza przywódcy tureccy nie wpadli w rozpacz, ale roztropnie postanowili aby śmierć zataić, tak przed nieprzyjaciótmi, jak swoimi ludźmi, którzy o tym nie wiedzieli. A w istocie jest to lud, który twardo trwa w milczeniu, kiedy trzeba ukryć własne nieszczęście. Ani strachem ani obietnicami nie można ich namówić aby wydali to co ich przywódcy chca by zostało ukryte. I tak, zanim to wszystko wyszło na jaw na wielkie tureckie niebezpieczeństwo, poprowadzili oddziały do boju, i wszystko to co musieli czynić aby się pokazać przed cesarzem, teraz czyniq dla swego własnego ratunku. Odważnie uderzyli na przeciwnika. Patrz: Commentaria..., t. I, s. 263.

${ }^{35}$ Wiemy, że w rzeczywistości Lazar, wzięty do niewoli, został ścięty po bitwie wraz z innymi serbskimi możnymi. Por.: . Commentaria..., t. I, s. 265; K. Jireček, Istorija Srba, Beograd 1952, vol.1, s. 325 .

${ }^{36}$ Ponieważ Tubero wyraźnie myli postaci i plącze się w chronologii wydarzeń nie sposób stwierdzić o jakiej bitwie tu mowa. Może jest to jakieś echo starcia pod Pločnikiem nad Toplicą z 1386 r.? Por.: Commentaria..., t. I, s. 266; K. Jireček., Istorija..., s. 324.

${ }^{37}$ Bitwę z cesarzem Zygmuntem Luksemburgiem pod Nikopolis stoczył w istocie w 1396 r. sułtan Bajezyd I, a zakończyła się ona kompletną klęską wojsk chrześcijańskich. Co ciekawe, Zygmunt w swej długiej tułaczce po bitwie na pewien czas trafił do Dubrownika, gdzie został gościnnie przyjęty. Pamięć o tym ważnym wydarzeniu musiała być długo żywa w mieście i dość dziwne jest, że Tubero o tym nie słyszał. Patrz: J. Tadić, Promet putnika u starom Dubrovniku, Dubrovnik 1939, s. 154-156.
} 
podporzadkowat Dardanię Trybalię Mezję i Macedonię z cała Grecja, oprócz Peloponezu ${ }^{38}$. Ciekawy - i dość bliski prawdy - jest opis wydarzeń związanych z akcją króla Władysława Warneńczyka w dobie bitwy pod Warną. Widać sprawa ta była żywa w świadomości dubrownickich elit. Ten [Władysław - P.W.] namówiony przez papieża złamat porozumienie $i$ w czasie rozejmu podją walkę z Turkami, ale z nieszczęsnym wynikiem. Mianowicie zostat zabity ku wielkiej weneckiej hańbie wspólnie z kardynałem Julianem Cesarini, kiedy w czasie walki, zachowujac sie jak zwycięzca, nieprzemyślanie rzucił się na tabor nieprzyjacielski, gdyż drugie węgierskie skrzydło, którym dowodził Jan Hunyadi, ojciec Macieja Korwina, Turków zmusiło do ucieczki ${ }^{39}$.

W powyższym fragmencie dziwić nieco może wzmianka o „weneckiej hańbie” i wymaga pewnego wyjaśnienia. Otóż to właśnie Wenecjanom (a nie Genueńczykom, jak czyni to większość współczesnych badaczy!) Ludwik Tuberon przypisuje przewiezienie wojsk Mahometa z Azji do Europy przed bitwą warneńską, co przypieczętowało los wyprawy z 1444 roku. Według pisarza Wenecjanie bali się pełnego sukcesu wyprawy i dotarcia Węgrów do Konstantynopola: Malebant autem Veneti sibi potius quam Hungaris Constantinopolim dedi ${ }^{40}$.

Tuberon wskazuje, iż ...dzielność węgierska nie została zwyciężona razem z królem. Mianowicie, kiedy namiestnikiem [Węgrzy] ustanowili Jana Hunyadego, tak wytrwale walczyli z Turkami, że Murada wyparli z Serbii, i odnowili w niej ksiażęca władzę Jerzego, wnuka owego Lazara o którym mówiliśmy wcześniej. Dalej, podkreślając rolę własnej małej ojczyzny w tych wydarzeniach, pisarz wzmiankuje, że wygnany władca serbski Jerzy Branković, schronił się początkowo właśnie w Dubrowniku, skąd uzyskał poradę i poparcie dla swych działań w Budzie ${ }^{41}$.

Pisarz zgodnie z prawdą informuje, że Murad II zmarł w zaawansowanej starości, jednak zdaje się nic nie wiedzieć o perturbacjach związanych z przejęciem tronu przez Mehmeda II. Jego charakterystyka młodego sułtana nie pozostawia wattpliwości co do żywionych przez Ludwika uczuć: Ten wszystkich osmańskich cesarzy przewyższat tak wiarołomnościa, chciwościa, lubieżnościq i okrucieństwem, jak i wielkościa swego imperium ${ }^{42}$. Dość szeroko, choć ogólnikowo, opisał następnie podboje Mehmeda. Zaczyna od zdobycia Konstantynopola, jednak - co warto podkreślić temu przełomowemu wydarzeniu poświęca zaledwie jedno zdanie. Podobnie krót-

\footnotetext{
${ }^{38}$ Por.: Commentaria..., t. I, s. 266; G. Agoston, MuradII(1421-1444,1446-1451) [w:] Encyclopedia..., s. $399-401$.

${ }^{39}$ Por.: Commentaria..., t. I, s. 267; K. Olejnik, Władysław III Warneńczyk (1424-1444), Kraków 2007, s. $170-224$

${ }^{40}$ Por.: Commentaria..., t. I, s. 267; F. Babinger, Z dziejów imperium Osmanów. Sultan Mehmed Zdobywca i jego czasy, Warszawa 1977, s. 47.

${ }^{41}$ Despota Jerzy Branković zagrożony przez Turków musiał opuścić kraj i dwukrotnie w $1440 \mathrm{r}$. i 1441 r. przebywał w Dubrowniku. Oczywiście w istocie był to tylko drobny epizod, choć z uwagi na niebezpieczeństwo dla miasta, istotny dla Republiki Dubrownickiej. Por.: Commentaria..., t. I, s. 267; J. Tadić, op. cit., s. 74-88.

${ }^{42}$ Commentaria..., t. I, s. 268.
} 
ko wspomina o podboju Peloponezu i „przepędzeniu” stamtąd greckiego cesarza ${ }^{43}$. Dalej stwierdza: Na koniec pod swa władzę [Mehmed - P.W.] zagarnat wszystkie ziemie między Dunajem Morzem Egejskim i Jońskim, oraz prawie cała Ilirię wyjquszy wybrzeża Dalmacji i tych krajów nad Neretwa i Vrbasem, które uznaja zwierzchność królów węgierskich. Potem możnych z tych obszarów wezwat do siebie i haniebnie pozbawit ich życia, choć wcześniej zagwarantowat im bezpieczeństwo ${ }^{44}$. Eliminacja miejscowej elity, była stałym elementem tureckiej polityki podboju, dlatego ostatnie spostrzeżenie, choć ogólnikowe, jest w zasadzie prawdziwe.

Tuberon wspomina jednak, iż mimo sukcesów w podbojach Mehmed ponosił jednak i porażki i sam znajdował się niekiedy w niebezpieczeństwie (...ita non sine suo ipsius periculo tot regna subegit). Wśród niepowodzeń sułtana dubrownicki pisarz wymienił utratę dwóch miast tj. Szabaca oraz Jajce, które podbił osobiście król Węgier Maciej Korwin ...w których i dzisiaj [Węgrzy] trzymaja swe załogi ${ }^{45}$. Informuje również o stosunkowo mało znanym wydarzeniu, które wydarzyło się blisko granic Dubrownika. Bośniacki możny, Władysław Kosača (Vuladislauo Cossicio) na czele miejscowych Wołochów (quos Valachos uulgo dicunt) uderzył wojska tureckie znienacka, gdy Mehmed, bez przedniej straży przechodził przez góry w Dalmacji. Turcy w popłochu uciekli pozostawiając tabory i tylko dlatego, że ...prostacy zadowolili tupem, (...agrestes praeda contenti) chrześcijanie pozwolili by sułtan się wymkną ${ }^{46}$.

Dalej zgodnie z prawdą Tuberon zauważył, że Mehmed w trakcie swego panowania zagarnął niemal całkowicie wybrzeża Morza Czarnego przy czym, jak pisze, ...Tatarom odebrał Krym ${ }^{47}$. Dubrownicki pisarz podkreślił z naciskiem, że w długotrwałych walkach z Węgrami, zwłaszcza na terenie Siedmiogrodu, wojska tureckie nigdy nie zdołały Madziarów ostatecznie pokonać. Wodzowie Mehmeda ponosili nawet spektakularne klęski, jak np. w bitwie na Cereris Campus koło Kolozsvaru (Alba Iulia) gdzie ...z czterdziestu tysięcy ludzi ledwie pięć setek wrócito do domu ${ }^{48}$.

43 Ostatni cesarz - Konstantyn XI Paleolog zginął podczas oblężenia Konstantynopola w 1453 r. . Tuberon wzmiankuje tutaj ,przepędzenie” w 1460 r. z Morei brata cesarza despoty Tomasza Paleologa, z którym Dubrowniczanie byli w bardzo dobrych stosunkach. Patrz: D.M. Nicol, Konstantyn XI, ostatni cesarz Bizancjum, Gdańsk 2004, s. 65-89, 102-108.

${ }^{44}$ Por.: Commentaria..., t. I, s. 268; ; C. Heywood, Mehmed II Fatih (1444-1446, 1451-1481) [w:] Encyclopedia..., s. 364-368.

45 Jajce Węgrzy odebrali Turkom w 1463 r. a Szabac w 1476. Patrz: Commentaria..., t. I, s. 269.

${ }^{46}$ Nie wiadomo o jakim ataku Bośniaków na wojska sułtana wspomina Tuberon. W każdym razie mało prawdopodobne aby w istocie chodziło w tym fragmencie o starszego syna hercega Stefana Vukčicia Władysława. Mowa jest raczej o jego młodszego bracie Vlatku, który w czasie swych rządów w Hercegowinie często podejmował działania przeciw Turkom. Por. Commentaria ..., t. I, s. 269; V. Atanasovski, Pad Hercegovine, Beograd 1979, s. 19-61.

${ }^{47} \mathrm{~W}$ istocie mowa tutaj o narzuceniu Tatarom krymskim zwierzchności w $1478 \mathrm{r}$.

${ }^{48}$ Chodzi o wydarzenie z 1479 r., kiedy oddziały wojewody Stefana Batorego pobiły wracające z łupem z wyprawy na Siedmiogród liczne wojska tureckie. Patrz: I.A. Fessler, Geschichte von Ungarn, B. 3., Leipzig 1874, s. 133-134. 
Opisując śmierć Mehmeda, Ludwik wspomina o plotkach dotyczących jego otrucia przez syna - Bajezyda ${ }^{49}$. Według niego, stary sułtan rozważał wcześniej zamordowanie starszego syna aby utorować drogę młodszemu Dżemowi (Gemius), którego ...ojciec bardzo go kochat $i$ wysoko cenit z powodu jego wygladu zewnętrznego ${ }^{50}$.

Swą krótką dygresję na temat dziejów Osmanów Tuberon zakończył opisem tureckich zwyczajów. Jest to fragment o tyle niezwykły i ciekawy, iż obraz Turków jaki się z niego wyłania odbiega wyraźnie od negatywnego wizerunku pojawiającego się na wielu innych stronach Commentarii.

Ludwik zwrócił uwagę, że Osmanowie odnoszą zwycięstwa (pomijając gnuśność chrześcijan i ich wzajemne spory), ponieważ jest to: ...lud, który bardzo dobrze znosi wysiłek, głód, upaty i mrozy, i za chwatę $i$ stawe swego cesarza gotów jest zgodzić się na wszelkie niedole, nawet na śmierć. Ich schronieniem są skromne szałasy z liści i słomy, zaś podczas wypraw zadowalają się skromnym odzieniem. Również pożywienie Turków jest proste, a piją jedynie mleko lub wodę źródlaną dosładzaną miodem, kiedy składają ofiary. Najwyżej cenią rzemiosło wojenne ...dlatego bardzo zręczni sq w jeździe konnej i strzelaniu z łuku. Swe zwycięstwa Turcy przypisują zawsze pomocy Bożej, natomiast porażki tłumaczą własnym niedbalstwem ${ }^{51}$.

Ludwik - mnich benedyktyński - wyraźnie idealizuje relacje społeczne w społeczeństwie tureckim. Jak pisze, bieda nie jest u nich powodem do wstydu a o znaczeniu człowieka nie stanowi bogactwo ani starożytność rodu, ale zdobywa się je na polu walki. Dlatego też wolny czas [od wojen -P.W.] znosza gorzej niż chorobę. Tuberon podkreśla rolę takich cnót jak gościnność i dotrzymywanie danego słowa. Gościnność jest u nich taka świętościa, że za grzech maja zaszkodzić komuś z kim się pożywiało, chociażby natknęli się na niego jako na nieprzyjaciela w starciu zbrojnym, uważajac, że żadna bitwa nie może być wyżej od przyjaźni. Do tego dane słowo i przysięgę większości każdy z nich ceni wyżej nie tylko ponad wszystkie bogactwa, ale i samo życie. Mianowicie całkiem wiarygodna jest opinia, że rzadko kiedy znajdzie się Turek, który by - i bez świadków albo jakiegoś pisemnego dokumentu - odmówił zwrócenia pożyczonych pieniędzy, ponieważ uważaja, że tego kto uczynitby takie przestępstwo czeka ciężka kara w piekle ${ }^{52}$.

Jednak cnotą, którą - według Tuberona - Turcy opanowali w najwyższym stopniu było posłuszeństwo wobec sułtana. Skazani przez władcę na śmierć bez najmniejszej skargi podporządkowywali się okrutnemu rozkazowi. Dla zilustrowania tej niezwykłej cechy, pisarz przytacza przykład Mehmeda Angelovicia, który wiedząc o grożącym wyroku i zachęcany przez przyjaciół do ucieczki, odmówił, gdyż nie chciał splamić swego honoru nieposłuszeństwem. Angelović stwierdził przy tym z charak-

49 Tuberon nie zauważa, że zgodnie z jego opowieścią byłby to już trzeci sułtan o imieniu Bajezyd. W istocie mowa o Bajezydzie II. Por: Commentaria..., t. I, s. 271; G. Agoston, Bayezid II (1481-1512) [w:] Encyclopedia..., s. 81-84.

50 O głośnej sprawie Dżema patrz: Z Morawski, Epilogi krucjat w XV w. Kraków 1924, s. 34-55.

51 Commentaria..., t. I, s. 271-272.

52 Commentaria..., t. I, s. 272-273. 
terystycznym dla muzułmanów fatalizmem: jakikolwiek mi koniec los wyznaczył chętnie go przyjme $e^{53}$.

Przeprowadzona wyżej analiza fragmentu z Commentarii autorstwa Dubrowniczanina Ludwika Tuberona de Crieva dotyczącego dziejów Turków pozwala na wyciągnięcie kilku wniosków:

1. Zamieszczenie w Commentarii obszernej dygresji poświęconej historii Turków było odpowiedzią na duże zainteresowanie jakie tematyka ta wywoływała w szesnastowiecznej Europie. Potwierdza to wydrukowanie obszernych fragmentów z tego dzieła jako odrębnego traktatu.

2. Autor usiłował dać pełny wykład dziejów Turków począwszy od ich odległej genezy aż po czasy Bajezyda II. Unika przy tym podawania dat. Czasy późniejsze przedstawił w innych częściach Commentarii (nie były one przedmiotem niniejszej analizy), uznając słusznie, że łączą się one tematycznie z wypadkami mu współczesnymi.

3. Na początku swych wywodów Tuberon wzmiankuje, że znane mu były teksty „scytyjskich autorów”, co może sugerować, że zapoznał się z jakimiś dziełami tureckimi. Być może w tym należy szukać przyczyny, iż Dubrowniczanin dość sporo pisze o migracji Turków oraz pierwszych władcach osmańskich.

4. Na tle niezłej znajomości wczesnych dziejów Turków uderzająco słabo zna autor wydarzenia z drugiej połowy XIV i pierwszej połowy XV w. Nie tylko ma problemy z prawidłowym podaniem właściwej kolejności tak fundamentalnych wydarzeń jak bitwa na Kosowym Polu, bitwa pod Nikopolis czy pod Ankarą ale myli także tureckich władców.

5. Panowanie Murada II i Mehmeda Zdobywcy znane jest Tuberonowi nieco lepiej, dostrzec można jednak, iż szerzej wspomina o wydarzeniach trzeciorzędnych rozgrywających się blisko Dubrownika (np. akcja młodego Kosačy przeciw Turkom) niż o wydarzeniach o znaczeniu fundamentalnym (zdobycie Konstantynopola), które toczyły się dalej.

6. Mimo generalnej niechęci do Turków (zwłaszcza do ich władców), opisując zwyczaje tureckie Tuberon potrafi wymienić ich cechy pozytywne, zwłaszcza te, które czyniły z nich groźnego przeciwnika.

${ }^{53}$ Tamże, s. 274. 


\title{
LUDWIK TUBERON DE CRIEVA (CRIJEVIĆ) THE BENEDICTINE FROM DUBROVNIK AND HIS OUTLINE OF THE HISTORY OF TURKEY IN THE POLITICAL MEMOIR COMMENTARII DE TEMPORIBUS SUIS
}

\author{
PIOTR WRÓBEL
}

\begin{abstract}
Summary
The knowledge of the religion, customs and past the Turks in the late medieval Dubrovnik was probably wider than in other Christian countries. However, until the end of the 15th century, Ottoman subjects were rather missing in the works of writers from Dubrovnik probably because of the censorship introduced by the government. One of the first writers from Dubrovnik who attempted to write a comprehensive history of Turkey was a Benedictine Louis de Crieva called Tubero (1458-1527). In the sixth book of his political memoir Commentarii de temporibus suis he provided a description of the origin, customs and outline of the history of the Turks. The analysis of this part of the work of Tuberona leads to several conclusions: 1) An extensive digression on the history of the Turks made by Tuberon was a response to a great interest in this topic in Europe in the 16th century. 2) the author attempted to give a full lecture of the history of Turks from their distant origins to the times of Bajezyd II 3) the early history of the Turks is presented correctly, but the author knows very little about the history of sultans in the 14th and the first half of the $15^{\text {th }}$ century. Tubero gives more information about sultan Murad II and Mehmed II 4) Tuberon can list many positive features in the Turks, especially those which made them a dangerous opponent.
\end{abstract}

